\title{
Addressing the Wealth Gap for Hispanic Families
}

Eric Rodriguez

\begin{abstract}
The author reflects on the racial and ethnic wealth gap and what it means for the Latino community and the national economy. In this article, the author examines several factors, including disparities in education, that contribute to the long-standing inequities facing Latino households. He also outlines key areas where policymakers must invest to create an agenda that reflects the American values of inclusivity and equitable treatment and results in opportunity for all Americans.
\end{abstract}

Federal Reserve Bank of St. Louis Review, First Quarter 2017, 99(1), pp. 53-58.

http://dx.doi.org/10.20955/r.2017.53-58

E vidence of a stark and widening wealth gap along racial and ethnic lines has brought renewed attention and urgency to the issue. The average Hispanic ${ }^{1}$ and Black family now has six and seven times less wealth, respectively, than a typical White family (Asante-Muhammad et al., 2016). Advocates and policymakers have brought the issue to public attention, and conversations around growing wealth inequality have become central to the debate leading up to the 2016 presidential elections. While various proposals for narrowing existing gaps have been introduced, we know that there is not one simple fix that will level the economic playing field.

Recent research from the Federal Reserve Bank of St. Louis illustrates the complexity of the wealth gap. The work by Emmons and Ricketts (2016) suggests that a college degree does not erase the wealth gap for Blacks and Latinos. Gaps exist even when accounting for other factors, including financial choices, intergenerational wealth transfers, and plain luck. The study draws attention to the influence of unobservable factors-including systemic racism and discrimination - on the wealth of hard-working communities of color, even when higher levels of education are attained. While deep and entrenched biases have an effect on the economic status of communities of color, it is important not to overlook the gains that the Latino community has made. A high-quality education remains an important piece in creating the

Eric Rodriquez is the vice president of the Office of Research, Advocacy and Legislation, National Council of La Raza. This article was prepared for remarks delivered at the symposium, "Does College Level the Playing Field? Racial and Ethnic Differences in Family Wealth Among College-Educated Families," sponsored by the Center for Household Financial Stability and the Research Division of the Federal Reserve Bank of St. Louis, May 25-26, 2016.

○ 2017, Federal Reserve Bank of St. Louis. The views expressed in this article are those of the author(s) and do not necessarily reflect the views of the Federal Reserve System, the Board of Governors, or the regional Federal Reserve Banks. Articles may be reprinted, reproduced, published, distributed, displayed, and transmitted in their entirety if copyright notice, author name(s), and full citation are included. Abstracts, synopses, and other derivative works may be made only with prior written permission of the Federal Reserve Bank of St. Louis. 
opportunity to accumulate wealth: It opens employment opportunities, provides skills necessary for our modern workforce, and improves educational prospects for subsequent generations.

The National Council of La Raza (NCLR) has worked to achieve equity and improve opportunities for Hispanics in the United States for nearly 50 years. We do this through policy advocacy and programs in several areas, including education, health, housing, and financial inclusion. We are uniquely positioned to listen to the Latino community. Our network of nearly 300 affiliate community-based organizations connects us with the community we serve and ensures that our policy advocacy and program work is authentic and will improve opportunities for Latinos.

This work is increasingly important as the country undergoes a demographic shift:

- By 2044, the United States as a whole will be majority-minority (Frey, 2014).

- Latinos in particular - who now total nearly 57 million-will make up a large proportion of the population growth in the coming decades (U.S. Census Bureau, 2016).

- The Latino population is young, with more than one-third younger than 18 years of age, and our country's education and workforce pipeline will be increasingly composed of Latino, Black, and Asian students and workers (Patten, 2016).

- Often, Latino families must also contend with an additional layer of complexity: immigration status. The unique effects of this added barrier follow individuals as they navigate our schools, labor, and financial markets.

As the population grows and our nation becomes increasingly dependent on Latino contributions, we must build the economic prosperity of the community. With respect to economic contributions, Latinos lead the country in labor force participation, and Latino buying power is projected to reach a staggering $\$ 1.7$ trillion by 2020 (Stepler and Brown, 2016; Nielsen Company, 2016). At the same time, Latinos make up the largest share of workers earning poverty-level wages, continue to see wages stagnate, and feel the effects of deepening wealth inequality (Economic Policy Institute, 2014). In 2013, the wealth of White households, based on median net worth, was $\$ 141,900$ versus $\$ 13,700$ for Hispanic households. The gap in wealth, $\$ 128,200$ in 2013, represents an increase from 2010 when there was a gap of \$122,600 (Kochhar and Fry, 2014).

\section{THE CHANGING LANDSCAPE OF LATINO EDUCATION}

Education has long been considered a key driver of economic opportunity and prosperity and is one of NCLR's core areas of work because we believe education is a civil right. We are encouraged to see that the educational outlook for Latinos has improved tremendously over the past few decades. From 1990 to 2013, the high school graduation rate for Hispanics increased from 59 percent to 85 percent (Musu-Gillette et al., 2016). Krogstad and Fry (2014) note that college enrollment among Hispanics ages 18 to 24 more than tripled (a 240 percent increase) between 1996 and 2012, outpacing increases among Blacks (72 percent) and Whites (12 percent).

Yet, disparities in educational quality between communities of color remain. We see that educational inequities begin in early childhood education, persist throughout the K-12 system, 
and impede a child's ability to succeed in postsecondary programs. If Latino students are underprepared for college and career after high school, or if they attend a postsecondary institution that does not serve them well, the wealth returns on their investment in education may not be as high or may not materialize at all. We have hope that the Every Student Succeeds Act will help Latino students and English learners close achievement gaps and increase their access to quality education to better prepare them for college and career.

Now that more Latinos than ever enter postsecondary institutions, we need to identify and address the complex factors affecting Latino students' experience in higher education and the returns on their investment. The affordability of higher education is increasingly a concern. As state investment in education remains below pre-recession levels, tuition continues to rise and financial aid covers a shrinking portion of costs, leaving many families to finance a larger portion of postsecondary education. To do so, they generally rely on student loans or pay more out of pocket. The effect of decreasing affordability on Latinos is becoming evident: Some Latino families contribute relatively higher amounts to their children's higher education costs than others (Sallie Mae, 2016). This could affect a family's financial security and ability to build wealth. Many Latino students feel they have no choice but to stay close to home or to attend a two-year public institution because of financial constraints. The type and quality of school attended can affect a student's completion and return on that investment in education. For example, two-year public institutions have been shown to have lower completion rates than more selective four-year institutions (Musu-Gillette et al., 2016). Additionally, the rise of for-profit colleges and their targeting of minority students has left many with debt and no degree, or a degree that provides a minimal, if any, return on investment (Huelsman, 2015).

\section{MOVING TOWARD EQUITY}

While education is a fundamental civil right and is a crucial part of providing improved opportunity for financial security, it alone cannot erase the wealth gap. There are other areas where our work tells us no single policy can make the path to financial security and upward mobility a reality for communities of color. For example:

- We know that it takes more than just hard work. Latinos are more likely than any other racial and ethnic group to be in the labor force, yet they are concentrated in low-wage jobs and are more than twice as likely to live in poverty than Whites (Stepler and Brown, 2016).

- We know that assets can narrow the gap, but traditional wealth-building tools are not always available to Latinos.

- Homeownership remains one of the primary paths to build wealth within the Latino community. In 2010, home equity accounted for 67 percent of net wealth for the median Latino homeowner, compared with 38 percent for the median White homeowner (Rockeymoore and Guzman, 2014). Consequently, the Latino community was among the hardest hit by the plummeting housing market leading up to the Great Recession and continues to struggle to make up lost ground. 
- Nearly half of Latinos remain outside the traditional banking system, with little to no access to banking products (Burhouse et al., 2014).

- Latinos are also the least likely racial and ethnic group to have access to a workplace retirement account (Rhee, 2013). Even when a savings or retirement account is available, near-term financial needs often compete for limited resources, making it difficult to build a nest egg.

Separately, none of these issues is simple to address. Taken together, these and other factors contributing to economic inequality will prove difficult, but not impossible, to change. Before leaders can intentionally reform and weave together targeted policies to level the economic playing field, they must understand the complexities of why families of color are being left behind. This will require a careful examination of how existing policies across the board influence the economic status of communities of color.

In the short and medium terms, however, national leaders have a tremendous opportunity to build on recent socioeconomic gains to help lead the nation toward greater economic equity. Federal policies that can support Latino economic security include the following:

- Restore the value of the minimum wage. The federal minimum wage should be raised to $\$ 15$ per hour by 2020 , followed by automatic increases to keep pace with rising costs. Nationally, the effects of a higher minimum wage would benefit more than 35 million workers.

- Expand access to refundable tax credits. A legislative change to expand eligibility for the Earned Income Tax Credit (EITC) could provide a much-needed boost to an estimated 13.5 million hard-working individuals, including 3 million Latinos. Expanding eligibility to receive the EITC to childless individuals and noncustodial parents could increase the average filer's credit by more than $\$ 340$.

- Enhance Latino retirement security. At the national level, there has been bipartisan support for an automatic individual retirement account to reach workers whose employers do not sponsor a retirement plan. With more than 60 percent of Latinos without access to an employer-based retirement plan, such a plan would improve their opportunity for a more secure retirement. Additionally, federal-level efforts to expand Social Security and increase access to and incentivize private retirement savings can also improve the retirement security outlook.

- Increase access to safe financial products. Strong consumer protections are necessary to ensure that individuals are shielded from predatory and discriminatory lending practices and financial products. Legislation and regulatory actions are needed to increase access to credit, provide strong consumer protections from predatory and discriminatory practices, and support individualized financial counseling, all essential aspects of a strong economy.

- Enact comprehensive immigration reform. Granting legal status and citizenship would have a positive economic effect for individuals and the country. Research shows that legal status and citizenship enable undocumented immigrants to produce and 
earn significantly more, and contribute more in taxes, than they do when they are on the fringes of the economy.

- Enable Latino homeownership. To ensure Latino households are able to enter the mortgage market, federal policies should reform the housing finance system so that it works for all creditworthy borrowers, especially first-time purchasers, communities of color, and other underserved communities. Federal funding for housing counseling programs is essential to ensure that Latinos can protect what, for many, is their greatest financial asset: their homes.

- Ensure effective implementation of the Every Student Succeeds Act. This legislation takes important steps to ensure equitable achievement among more students, including 13 million Latino students and 5 million English learners in U.S. schools. It is critical that stakeholders work together to ensure the law is implemented effectively, enhances accountability and achievement, and results in more students ready to succeed in college and career.

As the Latino community continues to drive growth, it is critical that national, state, and community leaders create and advance solutions that reward hard work and address longstanding inequities facing Latino households. Investing in an agenda that promotes the ideal of equitable treatment makes sound social, political, and economic sense because a stronger Latino community means a stronger America.

\section{NOTE}

1 The terms "Hispanic" and "Latino" are used interchangeably by the U.S. Census Bureau and throughout this document to refer to persons of Mexican, Puerto Rican, Cuban, Central American, Dominican, Spanish, and other Hispanic descent; they may be of any race.

\section{REFERENCES}

Asante-Muhammed, Dedrick; Collins, Chuck; Hoxie, Josh and Nieves, Emanuel. The Ever-Growing Gap: Without Change, African American and Latino Families Won't Match White Wealth for Centuries. Washington, DC: CFED and Institute for Policy Studies, 2016; http://cfed.org/policy/federal/The Ever_Growing Gap-CFED IPS-Final.pdf.

Burhouse, Susan; Chu, Karyen; Goodstein, Ryan; Northwood, Joyce; Osaki, Yazmin and Sharma, Dhruv. 2013 FDIC National Survey of Unbanked and Underbanked Households. Washington, DC: Federal Deposit Insurance Corporation, 2014; https://www.fdic.gov/householdsurvey/2013report.pdf.

Economic Policy Institute. "Share of Workers Earning Poverty-Level Wages, by Race and Ethnicity, 1973-2013." Washington, DC: Economic Policy Institute, 2014; http://www.stateofworkingamerica.org/chart/swa-wages-figure-4f-share-workers-earning/.

Emmons, William R. and Ricketts, Lowell R. "College Is Not Enough: Higher Education Does Not Eliminate Racial and Ethnic Wealth Gaps." Federal Reserve Bank of St. Louis Review, First Quarter 2017, 99(1), pp. 7-40.

Frey, William. "New Projections Point to a Majority Minority Nation in 2044." Washington, DC: Brookings, 2014; https://www.brookings.edu/blog/the-avenue/2014/12/12/new-projections-point-to-a-majority-minority-nation-in-2044/. 


\section{Rodriguez}

Huelsman, Mark. The Debt Divide: The Racial and Class Bias Behind The "New Normal" of Student Borrowing.

Washington, DC: Demos, 2015;

http://www.demos.org/publication/debt-divide-racial-and-class-bias-behind-new-normal-student-borrowing.

Kochhar, Rakesh and Fry, Richard. "Wealth Inequality Has Widened Along Racial, Ethnic Lines Since the End of the Great Recession." Washington, DC: Pew Research Center, 2014;

http://www.pewresearch.org/fact-tank/2014/12/12/racial-wealth-gaps-great-recession/.

Krogstad, Jens Manuel and Fry, Richard. "More Hispanics, Blacks Enrolling in College, but Lag in Bachelor's Degrees." Washington, DC: Pew Research Center, 2014; http://www.pewresearch.org/fact-tank/2014/04/24/more-hispanics-blacks-enrolling-in-college-but-lag-in-bachelors-degrees/.

Musu-Gillette, Lauren; Robinson, Jennifer; McFarland, Joel; KewalRamani, Angelina; Zhang, Anlan and WilkinsonFlicker, Sidney. Status and Trends in the Education of Racial and Ethnic Groups 2016. Washington, DC: U.S. Department of Education, 2016; http://nces.ed.gov/pubs2016/2016007.pdf.

Nielsen Company. From the Ballot Box to the Grocery Store: A 2016 Perspective on Growing Hispanic Influence in America. Washington, DC: Nielsen Company, 2016; http://www.nielsen.com/content/dam/corporate/us/en/ reports-downloads/2016-reports/nielsen-hispanic-consumer-report-2016.pdf.

Patten, Eileen. "The Nation's Latino Population Is Defined by Its Youth." Washington, DC: Pew Research Center, 2016; http://www.pewhispanic.org/2016/04/20/the-nations-latino-population-is-defined-by-its-youth/.

Rhee, Nari. Race and Retirement Insecurity in the United States. Washington, DC: National Institute on Retirement Security, 2013; http://www.nirsonline.org/storage/nirs/documents/Race\%20and\%20Retirement\%20Insecurity/ race and retirement insecurity final.pdf.

Rockeymoore, Maya and Guzman, Elvis. "The Racial Wealth Gap: Latinos." Washington, DC: Center for Global Policy Solutions, 2014; http://globalpolicysolutions.org/wp-content/uploads/2014/04/RacialWealthGap Latino Final.pdf.

Sallie Mae. How America Pays for College 2016. Newark, NJ: Sallie Mae Bank, 2016; http://news.salliemae.com/files/doc library/file/HowAmericaPaysforCollege2016FNL.pdf.

Stepler, Renee and Brown, Anna. Statistical Portrait of Hispanics in the United States. Washington, DC: Pew Research Center, Tables 22, 33, April 19, 2016; http://www.pewhispanic.org/2016/04/19/statistical-portrait-of-hispanics-in-the-united-states/.

U.S. Census Bureau. "Population Division, Annual Estimates of the Resident Population by Sex, Age, Race, and Hispanic Origin for the United States and States: April 1, 2010 to July 1, 2015." Washington, DC: U.S. Census Bureau, 2016. 